\title{
The use of incidence counts for estimation of cereal aphid populations. 3. Population development and the incidence- density relation
}

\author{
S.A. WARD ${ }^{1,3}$, K.D. SUNDERLAND 2 , R.J. CHAMBERS ${ }^{2}$ and A.F.G. DIXON ${ }^{1}$ \\ 1 School of Biological Sciences, University of East Anglia, Norwich NR4 7TJ, UK \\ 2 Glasshouse Crops Research Institute, Rustington, Littlehampton, W. Sussex BN16 3PU, UK \\ 3 Department of Theoretical Production Ecology, Agricultural University, P.O. Box 430, 6700 \\ AK Wageningen, the Netherlands
}

Accepted 5 March 1986

\begin{abstract}
The relation between the population density of the cereal aphid, Sitobion avenae, and the proportion of wheat tillers infested is examined. Three of the six models considered require the assumption that the aphids' spatial configuration can be described by a single statistical distribution; as this is not true for $S$. avenae these models are unsuitable. When the orher three models were applied to field sample data, only that of Nachman (1981) yielded a regression equation that remained constant throughout the development of the aphid population.
\end{abstract}

Additional keywords: Sitobion avenae, wheat.

\section{Introduction}

The high environmental costs of agricultural insecticides mean that strict decision rules are required, to avoid unnecessary applications. It is important, therefore, for farmers and biologists to be able to monitor the changing population densities of harmful species. The most direct method, counting the pest individuals on a number of host plants, may become prohibitively time-consuming if the pest is abundant. A number of authors have therefore suggested that 'incidence' (the proportion of plants infested) be measured instead (Pielou, 1960; Rabbinge et al., 1980; Rabbinge and Mantel, 1981, 1982; Reitzel, 1982). It has already been shown that, provided density and incidence are related, the use of incidence counts need not result in any significant loss of precision in estamation of populations (Ward et al., 1985a, 1985b). For this method to be used, however, any incidence-density relation must be reliable at all stages in the development of the population. If, for example, predator activity alters the distribution of the pests (Roitberg and Myers, 1978) the use of incidence counts may be unreliable:

The literature contains a number of suggested forms of the relation between density and incidence. This article reports on the use of field data to test whether any of these relations can be used to estimate the population density of the aphid Sitobion avenae (F.) from incidence counts, irrespective of the stage of development of the population. The data used were collected in Sussex during May and June, 1980, a year in which 
predator activity increased sharply during the summer and eventually resulted in the collapse of the aphid population (Chambers et al., 1986).

Sampling methods

S. avenae were sampled on early-sown winter wheat in May and June 1980, at ten sites in five fields on North Farm, Washington, Sussex. Aphids were counted on 100-400 tillers at the edge, and 100-400 tillers in the middle of each field. Each sampler counted the aphids on tillers in a small area, then moved some distance before sampling more tillers. The data could thus be treated in blocks of 25 or, by combining the results from adjacent groups, 50 tillers.

\section{The models}

I. Poisson. If organisms are distributed randomly among sampling units according to the Poisson distribution, the relation between mean density, $\mu$, and the proportion of sampling units unoccupied, $\mathrm{P}_{0}$, is

$P_{0}=e^{-\mu}$

However, most organinisms are strongly aggregated (Taylor et al., 1980), and it has been shown that populations of $S$. avenae can only rarely be described by the Poisson distribution (Rabbinge and Mantel, 1981).

II. Negative Binomial. This distribution gives

$\mathrm{P}_{0}=(1+\mu / \mathrm{k})^{-\mathrm{k}}$

where $\mathrm{k}$ is a constant. Although $S$. avenae populations are often distributed according to the negative binomial model, this is not always the case (Rabbinge and Mantel, 1981); and the value of $\mathrm{k}$ is strongly affected by the mean density (Rabbinge et al., 1984). This has also been shown for a wide range of other species (Taylor et al., 1979; Nachman, 1981).

III. Neyman A. This, the Poisson-Poisson distribution, yields

$\mathrm{P}_{0}=\exp \left[-\left(\mu / \mu_{2}\right)\left(1-\mathrm{e}^{-\mu_{2}}\right)\right]$

where $\mu_{2}$ is the mean number of individuals per cluster. This model is unsuitable because $\mu_{2}$ is normally unknown, and is unlikely to be constant in all conditions (Pielou, 1960).

In addition to the weaknesses specific to each of these models, the assumption that a population's spatial dispersion can always be described by a single statistical distribution is often untrue (e.g. Rabbinge and Mantel, 1981). This means that less demanding models must be sought.

IV. The probit model. Here, the relation between density and incidence is

Neth. J. Pl. Path. 92 (1986) 
Probit $\left(1-P_{0}\right)=A_{1}-B_{1} \log \mu$

where $A_{i}$ and $B_{1}$ are constants, to be estimated by regression. This model has been applied to populations of cereal aphids by a number of authors (Rabbinge et al., 1980; Rabbinge and Máantel, 1981, 1982; Reitzel, 1982).

V. Latteur's model. Latteur (1976) proposed that mean density can be expressed as a power function of the ratio of infested to uninfested sample units:

$\mu=\mathrm{A}_{2}\left(\frac{1-\mathrm{P}_{0}}{\mathrm{P}_{0}}\right)^{\mathrm{B}_{2}}$

where $A_{2}$ and $B_{2}$ are constants.

VI. Nachman's model. The decline in the number of empty sample units with increasing density is likely to be proportional to the number of empty sample units available for colonization, and to some increasing function of $\mu$. Assuming that this is a power function, Nachman (1981) derived the relation:

$\mathrm{P}_{0}=\exp \left[-\mathrm{A}_{3} \mu^{\mathrm{B}_{3}}\right]$

where the constants $\left(A_{3}\right.$ and $B_{3}$ ) are to be estimated by regression. This model was used successfully to describe data on the mites Tetranychus urticae and Phytoseiulus persimilis on cucumber (Nachman, 1981).

\section{Analysis}

In the sampling of insect pests it is desirable to minimize the ratio of the errors to the mean. This is equivalent to minimizing the error in estimates of $\log \mu$. Equations 4, 5 and 6 can be rearranged so that $\log \mu$ is linearly dependent on a transformation of $\mathrm{P}_{0}$.

From equation 4,

$\log \mu=a_{1}+b_{1}$ Probit $\left(1-P_{0}\right)$

where $a_{1}=-A_{1} / B_{1}$ and $b_{1}=1 / B_{1}$.

From equation 5 ,

$\log \mu=a_{2}+b_{2} \log \left[\frac{1-P_{0}}{P_{0}}\right]$

where $a_{2}=\log A_{2}$ and $b_{2}=B_{2}$.

From equation 6 ,

$\log \mu=a_{3}+b_{3} \log \left(-\ln P_{0}\right)$

where $a_{3}=-\left(\log A_{3}\right) / B_{3}$ and $b_{3}=1 / B_{3}$.

The parameters of these relations can be estimated for $S$. avenae by regression analysis of field results, using the sample mean, $\mathrm{m}$, as an estimate of $\mu$, and the propor-

Neth. J. Pl. Path 92 (1986) 


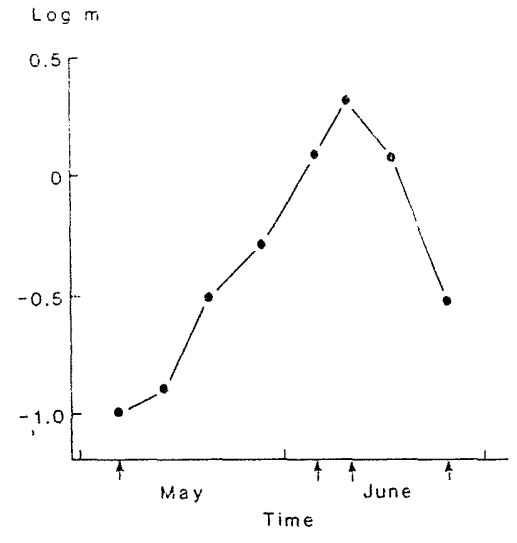

Fig. 1. Changes in the density of Sitobion avenae, $m$, on early-sown winter wheat in five fields on North Farm, Littlehampton, during 1980; $\uparrow$ : sample dates used in analysis.

tion of wheat tillers uninfested as a measure of $\mathrm{P}_{0}$.

To test whether any of these relations can be used, with constant parameters throughout the season, an analysis of covariance was performed, using the grouped data from each of the sampling sites. Each point thus represents the data on 100 to 400 tillers on a particular sample date. The analysis tested whether the data for all eight sample dates could be fitted by a single regression equation, or whether a separate equation was required for each week. Where one equation was found to be sufficient,

Table 1. Analysis of covariance. Grouped data, equation 7. For explanation see text.

$\begin{array}{llll}\chi^{2} & \text { d.f. } & \mathrm{F}\end{array}$

Homogeneity of variance (Bartlett's test)

7.76

Different means

Individual lines rather than individual means

One line rather than one rivean

$$
\text { (i.e., regression) }
$$

Individual lines rather than one line

Lines with common slope rather than individual means

Lines with common slope rather than one line (i.e.,

different intercepts

Individual lines rather than lines with common slope (i.e., different slopes)

NS: $p>0.05$; 
a further analysis of covariance was performed using the groups of 25 or, if this was impossible (owing to heterogeneity of variance), 50 tillers. For this second analysis, four sample dates were selected, to represent four very different stages in the population's development: 6.11ay (early in the exponential growth phase), 9 June (peak density, before the arrival of aphid-specific predators), 16 June (peak density of aphids and predators) and 25 June (during the period of rapid decline of the aphid population) (Fig. 1)

Results

Analysis of the grouped data. The results of the analyses of covariance are presented in Tables 1, 2 and 3 . The regressions based on equations 7 and 8 varied between sample dates: the slopes of the lines, $b_{1}$ and $b_{2}$, changed significantly during the period of observation. The data used here, therefore, could not be described by a single equation based on either of these two models.

The analysis based on equation 9, however, revealed no significant variation in either slope or intercept. The grouped data could, therefore, be adequately described by a single equation:

$\log m=0.33+1.13 \log \left[\ln \left(n / f_{0}\right)\right]$

Table 2. Analysis of covariance. Grouped data, equation 8. For further details see text.

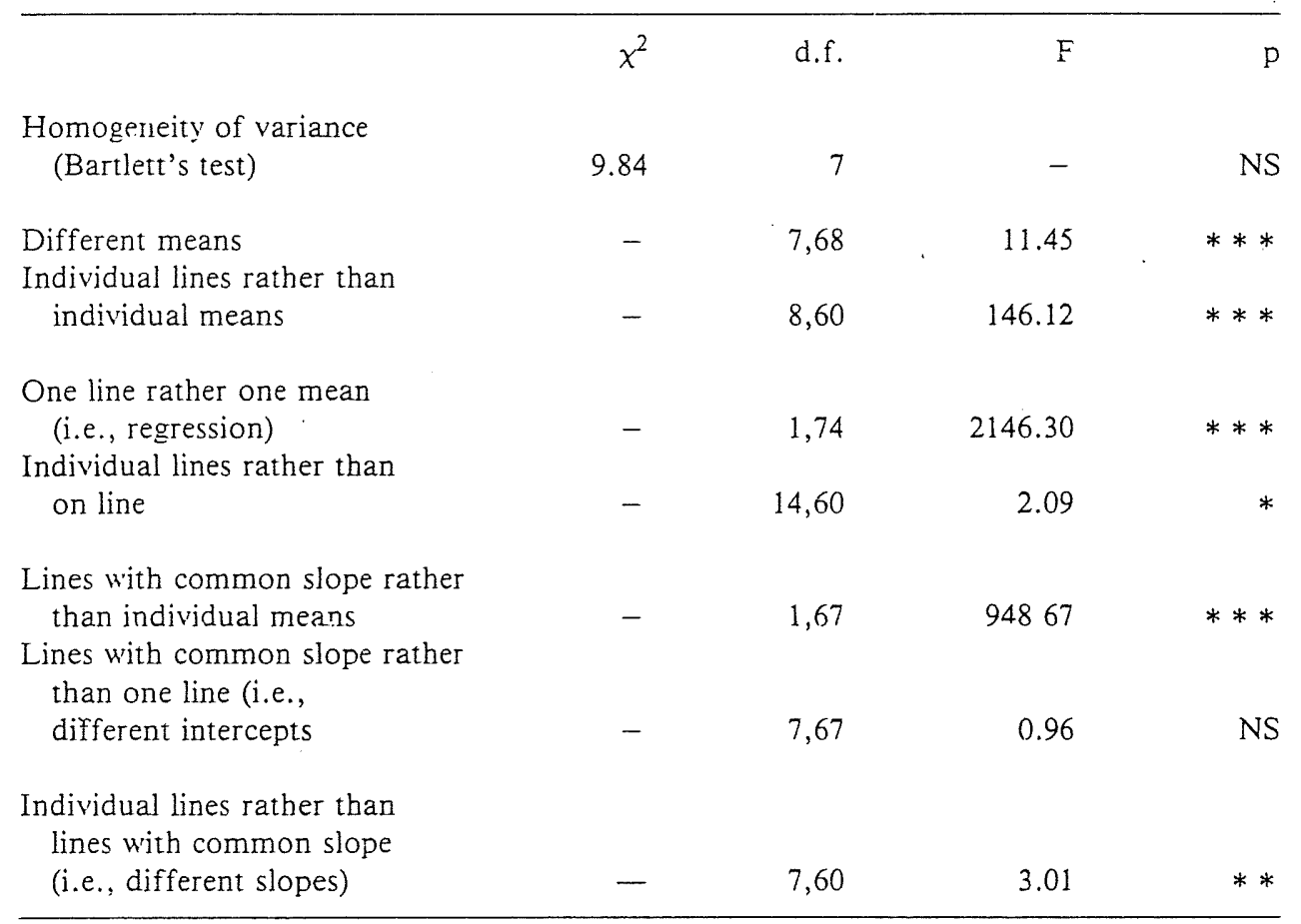

NS: $p>0.05 ; *: p<0.05 ; * *: p<0.01 ; * * *: p<0.001$.

Neth. J. Pl. Path. 92 (1986) 
Table 3. Analysis of covariance. Grouped data, equation 9. For explanation see text.

\begin{tabular}{lcccc}
\hline & $\chi^{2}$ & d.f. & F & p \\
$\begin{array}{l}\text { Homogeneity of variance } \\
\text { (Bartlett's test) }\end{array}$ & 13,12 & 7 & & NS \\
$\begin{array}{l}\text { Different means } \\
\text { Individual lines rather than } \\
\text { individual means }\end{array}$ & - & 7,68 & 11.45 & $* * *$ \\
$\begin{array}{l}\text { One line rather than } \\
\text { one mean } \\
\text { Individual lines rather than } \\
\quad \text { one line }\end{array}$ & - & 8,60 & 124.31 & $* * *$ \\
$\begin{array}{l}\text { Lines with common slope rather } \\
\text { than individual means } \\
\text { Lines with common slope rather } \\
\text { than one line (i.e., } \\
\text { different intercepts) }\end{array}$ & - & 1,74 & 2545.90 & $* * *$ \\
$\begin{array}{l}\text { Individual lines rather than } \\
\text { lines with common slope } \\
\text { (i.e., different slopes) }\end{array}$ & - & $1,6,60$ & 1.41 & NS \\
\hline
\end{tabular}

NS: $p>0.05 ; * * *: p<0.001$.

$\left(r^{2}=0.97,74\right.$ d.f., $\left.p<0.001\right)$ (Fig. 2) where $n$ is the number of tillers examined and $\mathrm{f}_{0}$ is the number of uninfested tillers.

Analysis of ungrouped data. The results from blocks of 25 tillers could not be subjected to analysis of covariance, since the variance about the lines (of the form of equation 9) was heterogeneous (Bartlett's $\chi^{2}=10.22,3$ d.f., $\mathrm{p}<0.05$ ). Table 4 shows the results of analysis of covariance using the data for blocks of 50 tillers. There is again no significant difference between the lines for the different sample dates; the single regression is:

$\log m=0.35+1.20 \log \left[\ln \left(n / f_{0}\right)\right]$

$\mathrm{r}^{2}=0.95,114$ d.f., $\left.\mathrm{p}<0.001\right)$

\section{Discussion and conclusions}

The time and effort required to monitor changes in aphid populations may be considerably reduced by use of incidence counts to estimate mean density. In this article, six forms suggested for the incidence-density relation have been considered. Of the six, three require the assumption that the population's spatial dispersion can always be described by a single statistical distribution. This assumption cannot be made for $S$. 


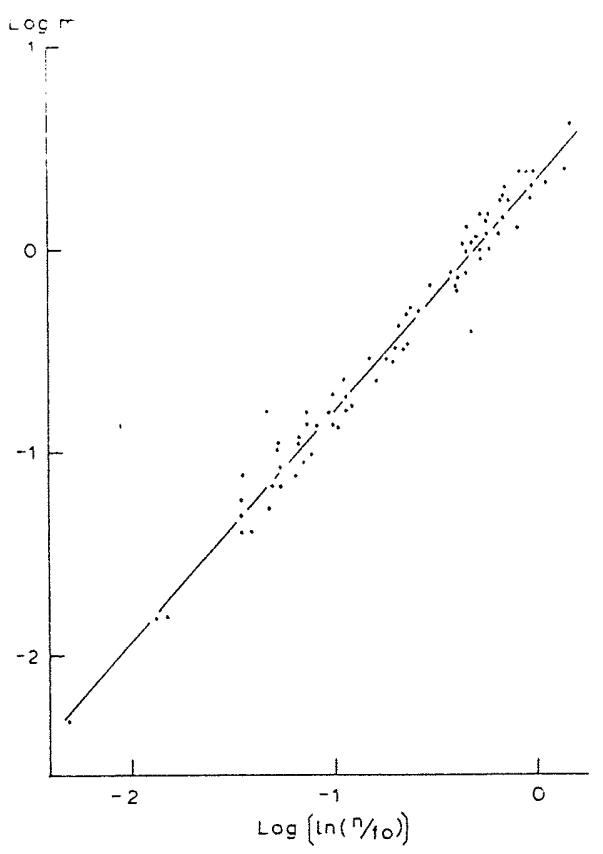

Fig. 2. The relation between the logarithm of the mean sample density (log $\mathrm{m}$ ) and Nachman's transformation of the proportion of wheat tillers infested by Sitobion avenae ( $\mathrm{n}$ $=$ number of tillers examined; $\mathrm{f}_{0}=$ number of tillers without aphids). Each of the 76 points represents the sample data from one site ( $\mathrm{n}=$ 100-400) on one day; data from all eight sample dates. Four points are omitted, since they represent samples in which no aphids were found, i.e. $\log m=\log \left[\ln \left(n / f_{0}\right)\right]=-\infty$.

Table 4. Analysis of covariance. Data from blocks of 50 tillers. Equation 9.

\begin{tabular}{|c|c|c|c|c|}
\hline & $x^{2}$ & d.f. & F & $\mathrm{p}$ \\
\hline $\begin{array}{l}\text { Homogeneity of variance } \\
\text { (Bartlett's test) }\end{array}$ & 5.66 & 3 & - & NS \\
\hline Different means & - & 7,112 & 44.07 & $* * *$ \\
\hline $\begin{array}{l}\text { Individual lines rather than } \\
\text { individual means }\end{array}$ & - & 4.108 & 250.20 & $* * *$ \\
\hline $\begin{array}{l}\text { One line rather than one mean } \\
\text { Individual lines rather than }\end{array}$ & - & 1,114 & 2370.52 & $* * *$ \\
\hline one line & - & 6,108 & 0.49 & NS \\
\hline $\begin{array}{l}\text { Lines with common slope rather } \\
\text { than individual mea:ss }\end{array}$ & -- & 1,111 & 1024.81 & $* * *$ \\
\hline $\begin{array}{l}\text { Lines with common slope rather } \\
\text { than one line (i.e., } \\
\text { different intercepts }\end{array}$ & - & 7,111 & 0.88 & NS \\
\hline $\begin{array}{l}\text { Individual lines rather than } \\
\text { lines with common slope } \\
\text { (i.e., different slopes) }\end{array}$ & - & 3,108 & 0.12 & NS \\
\hline
\end{tabular}

NS: $\mathrm{p}>0.05 ; * * *: \mathrm{p}<0.001$.

Neth. J. Pl. Poth. 92 (1986) 
avenae (Rabbinge and Mantel, 1981), so these three models are unsuitable.

The other three models, however, make no such assumption. The analysis presented above shows that, for data on S. avenue on winter wheat in Sussex in 1980, only one model yielded a regression equation that remained constant throughout the summer: the parameters of the models of Rabbinge et al.(1980) and Latteur (1976) varied significantly between sample dates; only model VI (Nachman, 1981) gave a single equation for all sample dates.

Further research is required to elucidate the mechanisms resulting in the relations between density and incidence, and thus to provide conclusions about the extent to which these results can be generalized.

\section{Acknowledgements}

The authors are grateful to David Stacey, for technical assistance, to the management of North Farm, Washington, Sussex, for permission to carry out field sampling, and to $\mathrm{Mr} \mathrm{J}$. Engelsman for drawing the figures. This article has benefited greatly from the thorough and constructive criticisms of Dr D.J. Aikman and Professors R. Rabbinge and J.C. Zadoks. S.A. Ward received financial support from the Agricultural Research Council.

\section{Samenvatting}

Het gebruik van incidentie voor het schatten van graanluispopulaties. 3. Populatieontwikkeling en de relatie tussen dichtheid en bezettingspercentage

Om in de praktijk gebruik te kunnen maken van incidentie (de fractie bezette halmen) voor het schatten van graanluispopulaties moet dezelfde relatie tussen dichtheid en incidentie tijdens het hele groeiseizoen gelden. Uit analyses van veldgegevens voor de graanluis Sitobion avenae blijkt dat wel het geval te zijn, zodat bepalingen van incidentie kunnen worden gebruikt om de populatiedichtheid betrouwbaar te schatten.

\section{References}

Chambers, R.J., Sunderland, K.D., Stacey, D.L. \& Wyatt, I.J., 1986. Control of cereal aphids in winter wheat by natural enemies: aphid-specific predators, parasitoids and pathogenic fungi. Ann. appl. Biol. (In press).

Latteur, G., 1976. Les pucerons des céréales: biologie, nuisance, ennemis. Mémoire no 3, Centre des Recherches Agronomiques de l'Etat, Gembloux. 74 pp.

Nachman, G., 1981. A mathematical model of the functional relationship between density and spatial distribution of a population. J. Anim. Ecol. 50: 453-460.

Pielou, D.P., 1960. Contagious distribution in the European red mite, Panonychus ulmi (Koch), and a method of grading population densities from a count of mite-free leaves. Can. J. Zool. 38: 645-653.

Rabbinge, R., Ankersmit, G.W., Carter, N.\& Mantel, W.P., 1980. Epłdemics and damage effects of cereal aphids in the Netherlands. Bull. S.R.O.P. 1980/III/4: 99-106.

Rabbinge, R., Kroon, A.G. \& Driessen, H.P.J.M., 1984. Consequences of clustering in parasitehost relations of the cereal aphid Sitobion avenae: a simulation study. Neth. J. Asgric. Sci. 32: $237-239$. 
Rabbinge, R. \& Mantel, W.P., 1981. Monitoring for cereal aphids in winter wheat. Neth. J. Pl. Path. 87: 25-29.

Rabbinge, R. \& Mantel, W.P., 1982. Monitoring and warning systems for cereal aphids in winter wheat. pp. 51-53. In: Bernard, J. (Ed.), Utilisation du piège à succion en vue de príoir les invasions aphidiennes. Euraphid, Gembloux.

Reitzel, J, 1982. Development of simple registration methods for forecasting cereal aphid infestations, especially in spring barley: pp. 54-55. In: Bernard, J. (Ed.) Utilisation du piège à succion en vue de prévoir les invasions aphidiennes. Euraphid, Gembloux.

Roitberg, B.D. \& Myers, J.H., 1978. Effects of adult Coccinellidae on the spread of plant virus by an aphid. J. appl. Ecol. 15: 775-779.

Taylor, L.R., Woiwod, I.P. \& Perry; J.N., 1979. The negative binomial as an ecological model and the density-dependence of $k$. J. Anim. Ecol. 48: 289-304.

Taylor, L.R., Woiwod, I.P. \& Perry, J.N., 1980. Variance and the large scale spatial stability of aphids, moths and birds. J. Anim. Ecol. 49: 831-854.

Ward, S.A., Rabbinge, R. \& Mantel, W.P., 1985a. The use of incidence counts for estimation of aphid populations. 1. Minimum sample size for required accuracy. Neth. J. Pl. Path. 91: 93-99.

Ward, S.A., Rabbinge, R. \& Mantel, W.P., 1985b. The use of incidence counts for estimation of aphid populations. 2. Confidence intervals from fixed sample sizes. Neth. J. Pl. Path. 91: 100-104. 